Tsumura, Y., K. Yoshimura, N. Tomaru and K. OhBA (1995): Molecular phylogeny of conifers using RFLP analysis of PCR-amplified specific chloroplast genes. Theor Appl Genet 91: 1222-1236.

WeIR, B. S. (1996): Genetic Data Analysis II. Sinauer Assoc, Sunderland, Mass.

WheELER, N. C. and K. S. JECH (1992): The use of electrophoretic markers in seed orchard research. New Forests 6: 311-328.
YAZDANI, R. and D. LINDGREN (1991): Variation of pollen contamination in a Scots pine seed orchard. Silvae Genet 40: 243-246.

Zhu, Y., H. Chen, J. FAn, Y. Wang, Y. Li, J. Chen, J. X. Fan, S. Yang, L. Hu, H. Leung, T. W. Mew, P. S. Teng, Z. WANG and C. C. MUNDT (2000): Genetic diversity and disease control in rice. Nature 406: 718-722.

\title{
Genetic Relationships among Schizolobium parahybum (Vell.) Blake (Leguminosae) Ecotypes from Ecuador and other Countries
}

\author{
By H. F. Canchignia-Martínez ${ }^{1)}$, S. Hernández-Delgado ${ }^{2)}$, M. GonzÁlez-Paz ${ }^{2)}$, E. Motte ${ }^{3)}$ and N. MaYek-PÉREz ${ }^{2), *)}$
}

(Received $8^{\text {th }}$ May 2006)

\begin{abstract}
Fifteen ecotypes of Schizolobium parahybum (Vell.) Blake collected in Ecuador (9), Brazil (3), Bolivia (1) Costa Rica (1), and Peru (1) were analyzed using Random Amplified Polymorphic DNA (RAPDs), Amplified Fragment Length Polymorphisms (AFLPs) and microsatellites (SSRs) in order to determine their genetic relationships and diversity patterns among ecotypes and to identify the origin of cultivated germplasm in Ecuador. Although AFLP markers were the most informative technique based on amplified products, SSRs clearly differentiated the ecotypes of Ecuador based on their geographical origin or genetic status into two groups: commercial ecotypes growing at western Ecuador very similar to the ecotype from Costa Rica, and native germplasm from eastern Ecuador and ecotypes from Brazil, Peru and Bolivia.
\end{abstract}

Key words: AFLP, genetic relationships, DNA-fingerprinting, RAPD, Schizolobium parahybum (Vell.) Blake, SSR.

\section{Introduction}

Forestry industry for wood production of Ecuador extensively exploits Schizolobium parahybum (Vell.) Blake ("pachaco", "guanacastle" or "palo de picho"). This species is largely distributed through America due it shows good adaptation to variable climate conditions and has great possibilities to continue its exploitation for wood production and other uses. Farmers from

\footnotetext{
1) Universidad Técnica Estatal de Quevedo. Avenida Quito km 1 Vía Santo Domingo. Quevedo, Los Ríos, Ecuador.

2) Centro de Biotecnología Genómica-Instituto Politécnico Nacional. Blvd. del Maestro esq. Elías Piña s/n, Col. Narciso Mendoza, 88710, Reynosa, México. Tel/Fax (899) 9243627.

3) Programa de Biotecnología - Universidad de Guayaquil. Av. Kennedy y Delta, Ciudadela Universitaria, A. Postal 471, Guayaquil, Ecuador.

*) Corresponding author: E-mail: nmayek@ipn.mx.
}

Ecuador are interested to establish orchards which show fast growth and the best wood quality for production of cellulose (MontenEgro, 1987). In 1950, S. parahybum was introduced to Quevedo, Ecuador by the Experimental Laboratory "Pichilingue" of the Instituto Nacional de Investigaciones Agrícolas y Pecuarias (INIAP). Although no data are available about the origin of the introduced germplasm, it has been assumed that it originated from Costa Rica. Therefore, no evidence is known about the origin of the most of commercial plantations in Ecuador, from Costa Rica or native germplasm. In Ecuador, $S$. parahybum is commonly propagated by seeds but no plant or seed pre-selection is done for the establishment of orchards and this fact has increased the genetic variability on commercial and native plantations (TIPAN, 1982).

The knowledge of genetic diversity and the relationships among genotypes will be important for the development of appropriate strategies for the in situ conservation of natural woods and the regeneration of partially logged forests of $S$. parahybum in Ecuador. This information can also serve as a baseline for determining whether genetic diversity has been lost through the sampling or conservation involving ex situ propagation, since those facts have been done in germplasm from Ecuador for plant improvement. Genetic diversity characterizations will be useful for planning a breeding strategy for commercial purposes. Genetic diversity of $S$. parahybum could be characterized based on morphological traits or using molecular markers which detect variation at the DNA sequence level. In particular, DNA-based polymorphisms are a powerful tool for assess genetic similarity between natural and breed genotypes.

The PCR-based techniques provide a representative sample of the genome and a virtually unlimited number 
of anonymous markers. Moreover, many of the polymorphisms revealed likely neutral (GONZÁLEZ and SIMPSON, 1997). Among the molecular marker methodologies we choose three of them for the genetic diversity analysis of S. parahybum: Random Amplified Polymorphic DNA (RAPDs), Amplified Fragment Length Polymorphisms (AFLPs) and Simple-Sequence Repeats (SSRs) or microsatellites. RAPD analysis is quick and well adapted for the efficient non-radiactive DNA fingerprinting of genotypes (WILliAMs et al., 1990), AFLP is a multi-locus marker technique developed by Vos et al. (1995) and generates genomic fragments detected after selective PCR amplification which provide a number of appealing features in the fingerprinting of genomes of different complexity. SSR polymorphisms occur frequently in plant genomes showing an extensive variation among individuals and accessions (WHITE and PowELL, 1997) and they are co-dominant markers. Currently, only a single report where 16 SSR loci were developed in $S$. parahybum from Belize has been published (KAMAU et al., 2003).

The objectives of the present work were: 1) to determine the genetic similarity in a set of ecotypes of $S$. parahybum from Ecuador and their genetic relationships with ecotypes from Bolivia, Costa Rica, Brazil, and
Peru and 2) to identify the origin of the S. parahybum germplasm commercially cultivated in Ecuador. Our hypotheses were: 1) SSR markers are the best system to characterize genetic diversity of $S$. parahybum based on amplified products, polymorphisms and correct identification of genetic relationships among ecotypes and 2) commercial germplasm of S. parahybum of Ecuador was developed from germplasm introduced from Costa Rica.

\section{Materials and Methods}

\section{Plant materials}

Seed samples were collected from 15 ecotypes of $S$. parahybum growing in different regions of Ecuador and other countries (Table 1, Figure 1). Each population consisted of one bulk of 15 seeds which were germinated and grown during four weeks under greenhouse conditions in Reynosa, México (26 $6^{\circ} 05^{\prime} \mathrm{LN}, 98^{\circ} 18^{\prime} \mathrm{LW} ; 38 \mathrm{~m}$ above sea level).

\section{DNA extraction}

Total genomic DNA was extracted using the procedure of Dellaporta et al. (1983). We used one leaf per plant from five plants per ecotype. Leaves were harvested 28 days after sowing. Tissues were macerated with liquid

Table 1. - Origin of 15 S. parahybum ecotypes from Ecuador and other countries.

\begin{tabular}{|c|c|c|c|c|c|}
\hline Ecotype & Origin & Genetic & Latitude & Longitude & Altitude \\
\hline & & status $^{a}$ & South & West & (m asl) \\
\hline 1 & El Padmi, Zamora, Ecuador & $\mathrm{N}$ & $04^{\circ} 07^{\prime}$ & $79^{\circ} 03^{\prime}$ & 500 \\
\hline 2 & Loma de Tigre, Oriente, Ecuador & $\mathrm{N}$ & $00^{\circ} 20^{\prime}$ & $77^{\circ} 15^{\prime}$ & 500 \\
\hline 3 & Santa Cruz, Bolivia & $\mathrm{N}$ & $13^{\circ} 40^{\prime}$ & $61^{\circ} 42^{\prime}$ & 500 \\
\hline 4 & Alcailadia, Brazil & $\mathrm{N}$ & $02^{\circ} 54^{\prime}$ & $66^{\circ} 27^{\prime}$ & 200 \\
\hline 5 & Rio Maria, Brazil & $\mathrm{N}$ & $03^{\circ} 31^{\prime}$ & $68^{\circ} 46^{\prime}$ & 200 \\
\hline 6 & Floresta Nacional, Brazil & $\mathrm{N}$ & $04^{\circ} 24^{\prime}$ & $65^{\circ} 58^{\prime}$ & 200 \\
\hline 7 & $\mathrm{CACH}$, Costa Rica & $\mathrm{N}$ & $09^{\circ} 29^{\prime}$ & $83^{\circ} 58^{\prime}$ & 500 \\
\hline 8 & Jumo, Perú & $\mathrm{N}$ & $03^{\circ} 25^{\prime}$ & $77^{\circ} 01^{\prime}$ & 500 \\
\hline 9 & Santa Rita-Pichilingue, Los Ríos, Ecuador & $\mathrm{C}$ & $01^{\circ} 05^{\prime}$ & $79^{\circ} 28^{\prime}$ & 50 \\
\hline 10 & Finca La Represa, Los Ríos, Ecuador & $\mathrm{C}$ & $01^{\circ} 03^{\prime}$ & $79^{\circ} 25^{\prime}$ & 50 \\
\hline 11 & San Carlos, Los Ríos, Ecuador & $\mathrm{C}$ & $01^{\circ} 06^{\prime}$ & $79^{\circ} 25^{\prime}$ & 50 \\
\hline 12 & Loma de Mera-Pichilingue, Los Ríos, & $\mathrm{C}$ & $01^{\circ} 05^{\prime}$ & $77^{\circ} 28^{\prime}$ & 50 \\
\hline \multicolumn{6}{|c|}{ Ecuador } \\
\hline 13 & Ventanas, Los Ríos, Ecuador & $\mathrm{C}$ & $01^{\circ} 25^{\prime}$ & $79^{\circ} 27^{\prime}$ & 50 \\
\hline 14 & La Mana, Cotopaxi, Ecuador & $\mathrm{C}$ & $00^{\circ} 55^{\prime}$ & $79^{\circ} 12^{\prime}$ & 50 \\
\hline 15 & Valencia, Los Ríos, Ecuador & $\mathrm{C}$ & $00^{\circ} 59^{\prime}$ & $79^{\circ} 21^{\prime}$ & 50 \\
\hline
\end{tabular}

a $\mathrm{N}=$ Native; $\mathrm{C}=$ Commercial. 


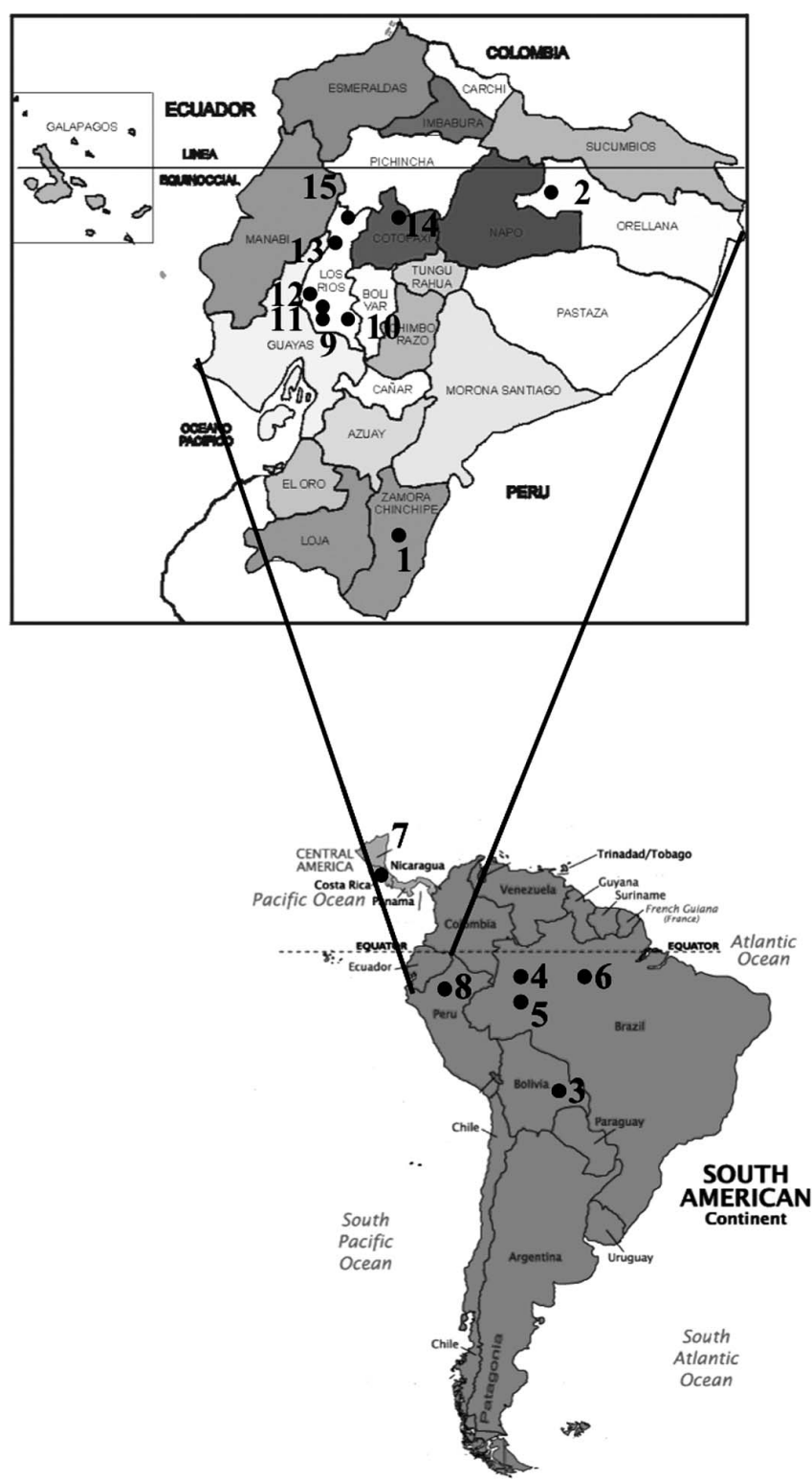

Figure 1. - Schizolobium parahybum ecotype origins. Numbers indicate the number of ecotype according to Table 1.

nitrogen and extraction buffer (100 mM Tris-HCl, $\mathrm{pH} 8$; $50 \mathrm{mM}$ EDTA; $500 \mathrm{mM} \mathrm{NaCl} ; 10 \mathrm{mM}$ mercapto-ethanol; SDS $1.3 \%$ ) was applied and the sample incubated to $65^{\circ} \mathrm{C}$ by $15 \mathrm{~min}$. After, sodium acetate was added and the homogenate was centrifuged to $17000 \mathrm{rpm}$ by 30 min. The supernatant was transferred to new tube, extracted with isopropanol and incubated to $-20^{\circ} \mathrm{C}$ overnight. After incubation the sample was centrifuged again and the supernatant incubated for $40 \mathrm{~min}$ to $37^{\circ} \mathrm{C}$ with RNase $\left(10 \mathrm{mg} \mathrm{mL}^{-1}\right)$. The DNA was precipitated using ethanol and re-suspended in TE (50 mM Tris- $\mathrm{HCl}$, $\mathrm{pH} 8 ; 10 \mathrm{mM}$ EDTA). DNA concentrations were visually estimated on $0.8 \%$ agarose gel stained with ethidium bromide $\left(1 \mathrm{mg} \mathrm{mL}^{-1}\right)$ using UV light.

\section{RAPD analysis}

The RAPD reactions (WILLIAMs et al., 1990) had $25 \mu \mathrm{L}$ of total volume which contained $20 \mathrm{ng}$ DNA, $2.5 \mu \mathrm{L}$ Buffer Taq, $0.2 \mu \mathrm{L}$ Taq DNA polymerase $\left(\right.$ Roche $\left.^{\circledR}\right), 1 \mu \mathrm{L}$
dNTPs $10 \mathrm{mM}, 3 \mu \mathrm{L}$ of each primer $2 \mu \mathrm{M}$ and $8.7 \mu \mathrm{L}$ of deionized water. Amplification consisted on one step of denaturation at $94^{\circ} \mathrm{C}$ for $2 \mathrm{~min}$, and 40 cycles of $94^{\circ} \mathrm{C}$ for $1 \mathrm{~min}, 37^{\circ} \mathrm{C}$ for $2 \mathrm{~min}$ and $72^{\circ} \mathrm{C}$ for $2 \mathrm{~min}$; a final extension step of $7 \mathrm{~min}$ to $72^{\circ} \mathrm{C}$ was applied. Amplified products were separated by electrophoresis in $1.2 \%$ agarose gels stained with ethidium bromide for $10 \mathrm{~min}$ and photographed with a digital camera under UV light. Twenty primers (OPA and OPC series from Operon Technologies Inc., Alameda, USA) were screened on three randomly chosen ecotypes. The ten primers that produced high intensity, easily scorable and reproducible bands were selected (OPA-02, OPA-12, OPA-16, OPA-15, OPC-01, OPC-04, OPC-07, OPC-08, OPC-09, and OPC-10). RAPD procedure was repeated twice in order to determine the repeatability of the analysis.

\section{AFLP analysis}

The AFLP procedure was performed as described Vos et al. (1995). Approximately $250 \mathrm{ng}$ genomic DNA were digested with $10 \mathrm{U}$ of EcoRI and $10 \mathrm{U}$ of Tru9I endonucleases to $37^{\circ} \mathrm{C}$ for $4 \mathrm{~h}$ and incubated to $70^{\circ} \mathrm{C}$ for 15 min. The DNA fragments were linked to EcoRI and MseI adapters to $15^{\circ} \mathrm{C}$ over-night. After pre-selective amplification by PCR using the nucleotide A, a selective amplification by PCR was performed with four combinations of $E c o R I+3 / M s e I+3$ primers. AFLP reactions were denatured by boiling with formamide buffer $(98 \%$ formamide, $10 \mathrm{mM}$ EDTA, bromophenol blue, xylene cyanol). All samples were separated by electrophoresis on $6 \%$ denaturing polyacrylamide gels $(35 \times 45 \mathrm{~cm})$ for $3 \mathrm{~h}$ at $2000 \mathrm{~V}$ and then revealed using the Silver Sequence Staining Reagents kit (Promega ${ }^{\odot}$; Madison, WI, USA).

\section{SSR analysis}

The SSR analysis was performed as described KAMAU et al. (2003) using the most informative SSR primer pairs (Sp1, Sp5, Sp9. Sp12, and Sp13). Reaction mix for PCR amplifications consisted on buffer Taq $2 \mu \mathrm{L}$ (50 mM $\mathrm{KCl}, 1.5 \mathrm{mM} \mathrm{MgCl}_{2}$ ), $1.6 \mu \mathrm{L}$ of each dNTP $10 \mathrm{mM}, 1 \mu \mathrm{L}$ of each SSR primer $2 \mu \mathrm{M}, 0.15 \mu \mathrm{L}$ of Taq DNA polymerase, and $30 \mathrm{ng}$ of genomic DNA. Amplification consisted on denature of DNA to $94^{\circ} \mathrm{C}$ for $3 \mathrm{~min}$; 30 cycles to $94{ }^{\circ} \mathrm{C}$ for $45 \mathrm{~s}$, the annealing temperature of each SSR primer for $45 \mathrm{~s}$ (KAMAU et al., 2003), and $72{ }^{\circ} \mathrm{C}$ for $2 \mathrm{~min}$; a final extension cycle to $72^{\circ} \mathrm{C}$ for $10 \mathrm{~min}$ was applied. Samples were separated by electrophoresis on $6 \%$ polyacrylamide gels for $2 \mathrm{~h}$ to $2000 \mathrm{~V}$ and then revealed using the Silver Sequence Staining Reagents kit. Gels were photographed under white light and documented using the Kodak Digital Science 1D (Eastman Kodak $\mathrm{Co}^{\odot}$, Rochester, USA), a software that determines the molecular weight of each revealed allele.

\section{Data analysis}

The RAPD and AFLP bands were visually scored as either present (1) or absent (0) in each DNA sample. Based on phenotype frequency, diversity values for each marker were calculated for each population using Nei's unbiased distances (NEI, 1978): 


$$
h_{k}=\frac{n}{n-1}\left(1-\sum_{i=1}^{n} p_{i}^{2}\right)
$$

where $p_{i}=$ frequency of a band in the population, and $n=$ number of individuals analyzed. Diversity values for each primer or primer combination were calculated as:

$$
H_{j}=\sum_{k=1}^{r} \frac{h_{k}}{r}
$$

where $r=$ number of markers revealed by each primer or primer combination. Diversity values of each population $(H)$ were calculated as the mean hi value over all markers.

Each pair-wise matrix was used to construct a dendrogram by the UPGMA (Unweighted paired grouping method with arithmetic averages) algorithm. SSR data were analyzed using Genetix 4.04 (BELKHIR et al., 2002) and the dendrograms were constructed by the UPGMA method using programs from the Phylip 3.65 package (FELSENSTEIN, 1989). In addition, genetic variation of each SSR locus was measured in terms of the number of alleles, the observed heterozygosity and gene diversity (NEI and LI, 1979). Genetic diversity indexes per marker system and population were calculated as has been previously described (PowELl et al., 1996). A bootstrap resampling was performed using DistAFLP software to determine the robustness of the dendrograms produced with each marker system (MougEL et al., 2002). One thousand bootstrap replicates were obtained from the original data and for each replicate a distance matrix (SKROCH et al., 1992) and a similarity matrix (NEI and
LI, 1979) were calculated. From these 1000 matrices, confidence limits for each pair-wise comparison were determined (FELSENSTEIN, 1985). To evaluate the relationship between the genetic similarities estimated from the marker systems, the Spearman correlation coefficients were calculated. In order to determine the significance of the grouping determined by each marker system, the original distance matrices were used to perform a summarized dendrogram using the UPGMA method and programs from the Phylip 3.65 package (FELSENSTEIN, 1989). The robustness of the summarized dendrogram was measured using the bootstrap re-sampling method. For each bootstrap replication the data matrix was re-sampled and the distance matrix reconstructed and reduced as described above. The topology of the resulting dendrogram was then compared with the topology of the dendrogram produced from each marker system One -thousand bootstrap replications were performed.

\section{Results}

The highest number of amplified bands was found using AFLPs (78 per AFLP primer combination) but the highest rate of polymorphic bands was obtained using SSRs. The number of bands and the number of phenotypes per assay unit were higher in AFLPs than any other marker system. The three marker techniques showed similar diversity indexes among $S$. parahybum ecotypes while ecotypes from Ecuador showed similar diversity indexes than those from other countries (Table 2). All SSR marker loci were polymorphic and 39 puta-

Table 2. - Level of polymorphism and comparison of informativeness obtained

\begin{tabular}{|c|c|c|c|}
\hline \multirow[b]{2}{*}{ Parameter } & \multicolumn{3}{|c|}{ Marker system } \\
\hline & RAPD & AFLP & SSR \\
\hline Number of assay units & 10 (primers) & $\begin{array}{c}4 \text { (primer } \\
\text { combination) }\end{array}$ & $\begin{array}{c}5 \text { (primer } \\
\text { pairs) }\end{array}$ \\
\hline Total number of bands & 171 & 312 & 42 \\
\hline Number of polymorphic bands & $163(95 \%)$ & $299(96 \%)$ & $42(100 \%)$ \\
\hline $\begin{array}{l}\text { Number of bands per assay } \\
\text { unit }\end{array}$ & 17.1 & 78.0 & 8.4 \\
\hline $\begin{array}{l}\text { Number of phenotypes per } \\
\text { assay unit }\end{array}$ & 16.3 & 74.8 & 8.4 \\
\hline Diversity index & & & \\
\hline Total & 0.87 & 0.88 & 0.87 \\
\hline Accessions from Ecuador & 0.88 & 0.89 & 0.88 \\
\hline $\begin{array}{l}\text { Accessions from other } \\
\text { countries }\end{array}$ & 0.86 & 0.86 & 0.86 \\
\hline
\end{tabular}
with RAPD, AFLP and SSR markers in 15 ecotypes of S. parahybum. 
Table 3. - Characteristics of the five SSR loci analyzed on 15 ecotypes of S. parahybum.

\begin{tabular}{|c|c|c|c|c|c|c|c|c|c|c|}
\hline $\begin{array}{l}\text { SSR } \\
\text { locus }\end{array}$ & Repeat motif & $\begin{array}{l}\text { Size } \\
\text { (bp) }\end{array}$ & $\begin{array}{l}\text { Number } \\
\text { of alleles }\end{array}$ & $\begin{array}{l}\text { OSR } \\
\text { (bp) }\end{array}$ & $\mathrm{A}_{\mathrm{T}}$ & $\mathrm{A}_{\mathrm{SH}}$ & $\mathrm{A}_{\mathrm{E}}$ & $\mathrm{A}_{\mathrm{NE}}$ & $\mathrm{H}_{\mathrm{O}}$ & $\mathrm{H}_{\mathrm{E}}$ \\
\hline Sp1 & $(\mathrm{GCC})_{7}$ & 177 & 5 & $156-198$ & 7 & 1 & 5 & 1 & 0.13 & 0.78 \\
\hline Sp5 & $(\mathrm{GA})_{14}$ & 183 & 5 & $155-211$ & 6 & 2 & 4 & 0 & 0.27 & 0.53 \\
\hline Sp9 & $(\mathrm{CT})_{15}$ & 242 & 8 & $212-272$ & 7 & 2 & 3 & 2 & 0.13 & 0.74 \\
\hline Sp12 & $(\mathrm{CA})_{2}(\mathrm{GA})_{16}$ & 187 & 5 & $156-223$ & 11 & 2 & 4 & 5 & 0.23 & 0.60 \\
\hline Sp13 & $(\mathrm{TA})_{3}(\mathrm{CA})_{12}(\mathrm{TA})_{4}$ & 191 & 4 & $153-229$ & 8 & 2 & 3 & 3 & 0.13 & 0.78 \\
\hline
\end{tabular}

a KAMAU et al. [6]. OSR = Observed size range; $\mathrm{A}_{\mathrm{T}}=$ Total number of observed alleles; $\mathrm{A}_{\mathrm{SH}}=$ Shared alleles; $\mathrm{A}^{\mathrm{E}}=$ Alleles unique to Ecuatorian ecotypes; $\mathrm{A}_{\mathrm{WO}}=$ Alleles unique to No-Ecuatorian ecotypes; $\mathrm{H}_{\mathrm{O}}=$ Observed heterozygosity; $\mathrm{H}_{\mathrm{E}}=$ Expected heterozygosity.

(a)
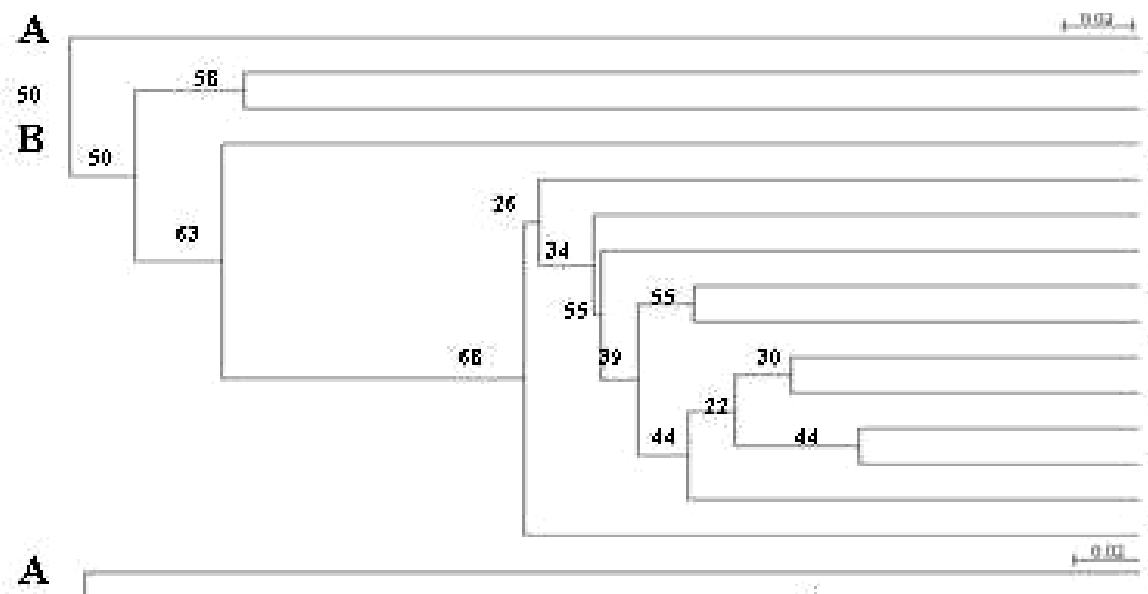

A

so

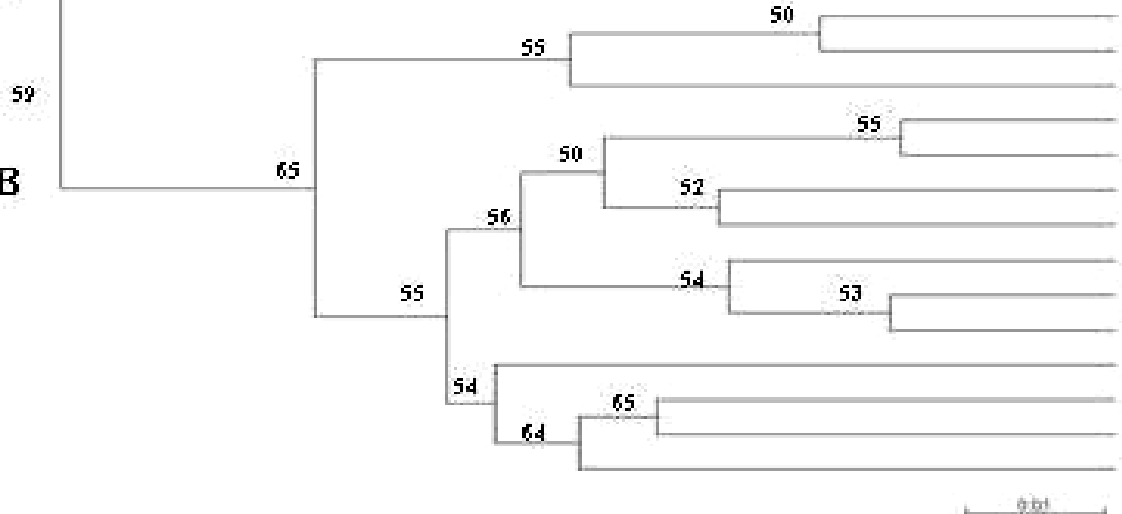

acuscon

acuscors

acuscons

scuscons

acturcons

acuxcon

DEसTAT

GRAATAT

GRAATAT

GRAAWAT

CR-MAT

BOCINAT

acuscon

ECUNATT

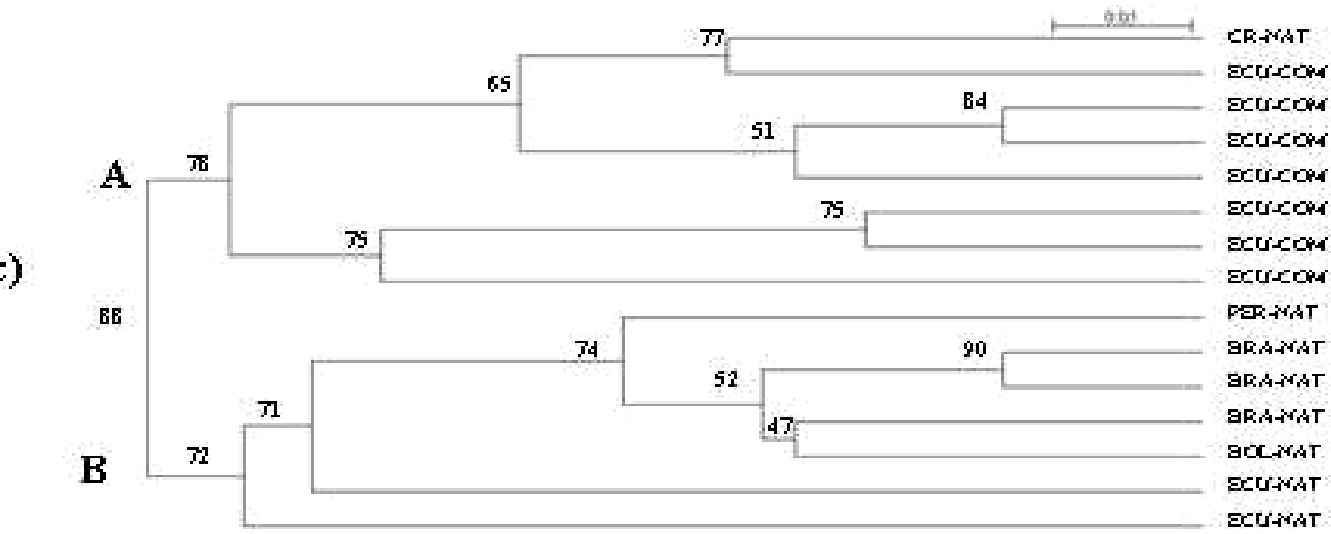

Figure 2. - Dendrograms of 15 S. parahybum ecotypes on basis to RAPD (a), AFLP (b) and SSR (c) data. Numbers above the branches represent bootstrap support values (\%) for 1000 replicates. The origin and genetic status is noted to the right of each dendrogram where ECU = Ecuador, BRA = Brazil, CR = Costa Rica, $\mathrm{BOL}=$ Bolivia, $\mathrm{PER}=$ Peru, $\mathrm{NAT}=$ Native, $\mathrm{COM}=$ Commercial . 


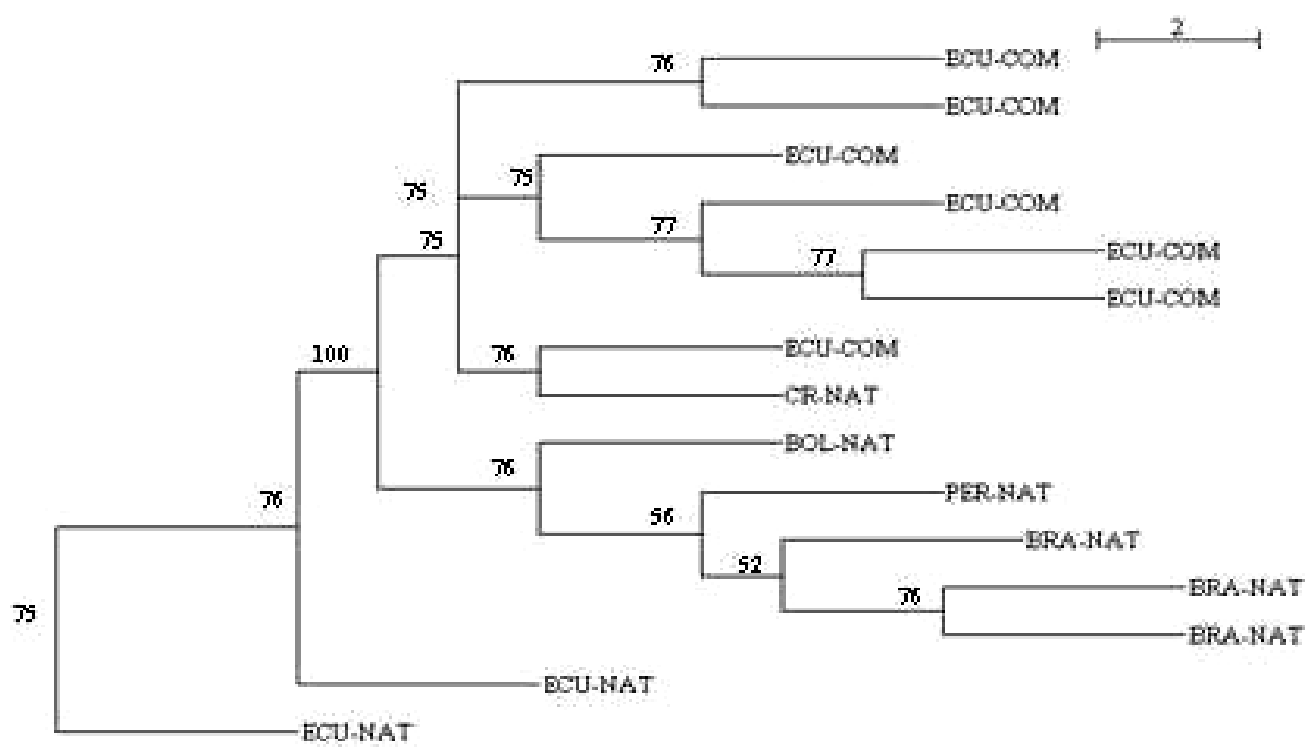

Figure 3. - Dendrograms of 15 S. parahybum ecotypes on basis to three marker system data. Numbers above the branches represent bootstrap support values $(\%)$ for 1000 replicates. The origin and genetic status is noted to the right of each dendrogram where ECU = Ecuador, $\mathrm{BRA}=$ Brazil, $\mathrm{CR}=$ Costa Rica, $\mathrm{BOL}=$ Bolivia $, \mathrm{PER}=\mathrm{Peru}, \mathrm{NAT}=$ Native, $\mathrm{COM}=$ Commercial .

tive alleles (different fragment sizes) were found. The number of alleles per locus ranged from 6 (for $\mathrm{Sp} 5$ ) to 11 (for $\mathrm{Sp12}$ ) with an average of 7.8 alleles per locus. The $23 \%$ of alleles were shared between ecotypes from Ecuador and other countries and $48.8 \%$ were unique to the ecotypes from Ecuador and $28.2 \%$ to ecotypes from other countries. The heterozygosity between $S$. parahybum ecotypes ranged from 13 to $73 \%$ with an average of $27.8 \%$ per locus (Table 3). The SSR analysis showed that commercial ecotypes cultivated at western Ecuador were highly similar to the ecotype from Costa Rica. Native ecotypes from eastern Ecuador were genetically different to commercial accessions but clustered with foreign ecotypes from Brazil, Bolivia, and Peru. The SSR method was the most robust molecular marker system to determine genetic relationships among $S$. parahybum ecotypes (Figure 2) despite SSR showed the lowest Spearman correlation coefficients among the three molecular marker systems. Data (number of amplified products per reaction) produced by SSR analysis were lower than those produced using RAPD or AFLP analyses (Table 2). A comparison of the dendrograms (Figure 3) indicated that SSR method more clearly separated the ecotype from Costa Rica and commercial ecotypes of Ecuador from all other native ecotypes from Ecuador, Brazil, Bolivia and Peru. The confidence limit for the separation of groups A and B based on SSR markers was $88 \%$ considerably higher than the $59 \%$ confidence limit for this separation observed based on bootstrapping of AFLP data and $50 \%$ of RAPD data (Figures 2 and 3 ).

\section{Discussion}

Comparison of molecular marker systems

The RAPD, AFLP and SSR markers have been compared in annual (maize, Zea mays L.) (PEJIC et al., 1998); fruit (olive, Olea europea L.) (BELAJ et al., 2003); and forestry (Pinus oocarpa) (DíAz et al., 2001) species.
In this work, AFLPs were the most efficient marker system due to their capacity to reveal the highest number of bands per reaction and efficiency indexes. However, the three marker systems were effective to detect genetic variation in $S$. parahybum since all individuals showed different genotypes and average diversity indexes were higher ( $>0.8$ ) than those reported in Pinus species (< 0.40 in $P$. oocarpa; 0.37 in $P$. sylvestris; 0.46 in P. contorta) (SzMIDT et al., 1996; THOMAs et al., 1999; Díaz et al., 2001), mainly due to the diverse origin on $S$. parahybum ecotypes. The RAPD marker system was highly reproducible since the two amplifications produced the same clustering among $S$. parahybum ecotypes (data not shown). Similar results were reported by SHARMA et al. (1996) and MULUVI et al. (1999). However, RAPD markers differed substantially in their ability to reveal diversity among $\mathrm{S}$. parahybum ecotypes (DíAz et al., 2001) compared to AFLPs and SSRs. Results confirm the need for using a large number of RAPD primers in order to prevent bias in the estimation of genetic parameters. In contrast, AFLP system produced fairly homogeneous estimates of diversity while SSRs clearly differentiated commercial from native ecotypes and establish the close relationship between commercial ecotypes from Ecuador and germplasm from Costa Rica.

Table 4. - Spearman correlation coefficients among three molecular marker systems applied in $S$. parahybum produced by using genetic distances matrixes generated for cluster analysis.

\begin{tabular}{llll}
\hline Marker system & AFLP & SSR & All \\
\hline RAPD & $0.99^{* *}$ & $0.91^{* *}$ & $0.99^{* *}$ \\
AFLP & & $0.91^{* *}$ & $0.99^{* *}$ \\
SSR & & & $0.92^{* *}$ \\
\hline
\end{tabular}

** Significant $(\mathrm{p} \leq 0.01)$ 
These results, together with the large number of AFLP markers scored per gel lane, counter the potential drawbacks of the AFLP technique such as more time-consuming, more technically demanding and more expensive than RAPDs (KARP and EDWARDS, 1995). FONTES et al. (2003) found that Pseudotsuga menziesii (Mirb.) Franco provenances of Portugal fell into a single poorly resolved group together with provenances collected across the native range of the species and the inability to resolve whether all Portuguese provenances were the product of a single or multiple introductions from the native range. The poor resolution could be caused by the marker strategy of analysis (isozymes) and the low number of loci analyzed (seven). The authors suggested the denser sampling of ecotypes in the native range and the use of a powerful molecular marker methodology such as microsatellites to clarify genetic relationships among forest individuals, populations and species.

\section{Origin of commercial S. parahybum ecotypes of Ecuador}

The SSR data clearly indicated the close relationship between commercial $S$. parahybum germplasm in Ecuador and ecotypes introduced from Costa Rica and grouped ecotypes based on geographical origin (commercial ecotypes from western Ecuador and native ecotypes from eastern). The origin of commercial $S$. parahybum germplasm of Ecuador from Costa Rica was strengthened by the comparison of dendrogram topologies as defined by the pattern of branching between ecotypes were different for each method and the highest confidence limits for relationships based on bootstrapping using SSRs. In addition, deficits of heterozygotes were detected for each SSR locus analyzed which indicate inbreeding and/or population substructure. Deficits could be explained by the limited sample size used in this work which was combined with the low number of SSR alleles amplified in the samples (Fontes et al., 2003; HARTL and ClARK, 1997). A certain degree of mating between related individuals would occur and be successful among ecotypes. Since ecotypes from Ecuador were closely related to the ecotype from Costa Rica, clear parent offspring relationship established would eventually lead to an excess of homozygotes (CHUNG et al., 2004). Microsatellite markers showed a clear differentiation between commercial and native $S$. parahybum ecotypes and a close relationship between commercial germplasm and the ecotype from Costa Rica. The differentiation based on genetic status due the variable frequency of alleles probably indicates no introgression between commercial and native ecotypes, the use of seeds from specific lots or provenances and/or poor gene flow among native and introduced populations, despite long cultivation history and similar flowering periods of different ecotypes (FonTES et al., 2003; Ho et al., 2002; RiBeIRo et al., 2002; SALVADOR et al., 2000).

\section{Implications for reforestation plans in Ecuador using S. parahybum}

The SSR analysis also confirmed that former reforestation programs conducted in Ecuador were performed using germplasm introduced from Costa Rica to the Experimental Laboratory Pichilingue of INIAP and no native ecotypes were included. From Pichilingue, new plants were dispersed to all western Ecuador and subsequently, genetic diversity was increased since commercial forest commonly established new plantations using sexual seeds (TIPAN, 1982). The establishment of forest plantations throughout the world demands increasing amounts of seeds annually. Seeds are often transferred between countries or between areas within countries, accompanied by inadequate information about their source and history. Therefore, reproductive material identification and certification has been an important issue in recent decades (JoNES and BuRLEY, 1973). Molecular marker analysis can be considered a helpful tool for conservation of $S$. parahybum in Ecuador. In fact, the germplasm included in this work constitutes the basis for future breeding programs where the production of new breed genotypes with tolerance to both biotic and abiotic stresses and good adaptation through the country are the major issues. Forestry researchers have recognized that the use of seeds with different geographical origins could contribute to differences on growth and phenotypic characteristics. These differences could be favorable or not favorable for the successful establishment of new plantations. The knowledge of seed origins and quality of any lot and their response to both abiotic (drought, salinity, acid soils) and biotic (diseases, pests) stresses must be taking into account to optimize the new forestry nurseries.

\section{Acknowledgements}

We acknowledge the suggestions for SSR analysis by A. M. Sifuentes-Rincón (CBG-IPN). H. F. CANChigniaMARTínez thanks to Universidad Tecnica Estatal de Quevedo, Ecuador for partial funding of this work. We also thank the partial funding to this work by FOMIXTamaulipas (TAMPS-2003-C03-06). N. Mayek-Pérez is S.N.I, COFAA-IPN and EDI-IPN fellow.

\section{References}

Belaj, A., Z. SAtovic, G. Cipriani, L. Baldoni, R. Testolin, L. RAllo and I. Trujillo (2003): Comparative study of the discriminating capacity of RAPD, AFLP and SSR markers and of their effectiveness in establishing genetic relationships in olive. Theor. Appl. Genet. 107: 736-744.

Belkhir, K., P. Borsa, L. Chikhi, N. Raufaste and I. BenHOMME (2002): Genetix (version 4.04), Logiciel Sous Windows ${ }^{\mathrm{TM}}$ pour la Genetique des Populations, Laboratoire Genome, Populations, Interactions: CNRS, UMR 5000. Universite Montpellier. Montpellier, France.

Chung, M. Y., M. G. Chung, E. R. Myers, J. M. Chung, K. J. KiM, C. W. PARK, B. Y. Sun and J. H. PARK (2004): Spatial genetic structure in distributed populations of Quercus acutissima (Fagaceae). Silvae Genet. 53: 206-211.

Dellaporta, S. L., T. Woods and J. B. Hicks (1983): A plant DNA minipreparation. Version II, Plant Mol. Biol. Rep. 1: 19-21.

DíAz, V., L. M. Muñiz, E. FerRer (2001): Random amplified polymorphic DNA and amplified fragment length polymorphism assessment of genetic variation in Nicaraguan populations of Pinus oocarpa. Mol. Ecol. 10: 2593-2603. 
FELSEnstein, J. (1985): Confidence limitson phylogenies: an approach using the bootstrap. Evolution 39: 783-791.

FELSENSTEIN, J. (1989): PHYLIP-Phylogeny inference package. Cladistics 5: 164-166.

Fontes, I., P. SAVILL, J. S. LUIS and S. HARRIS (2003): Identification of the origin of Portuguese Douglas-fir [Pseudotsuga menziesii (Mirb.) Franco] provenances. Silvae Genet. 52: 266-273.

GonzÁleZ, M. M. and J. Simpson (1997): Diversidad genética en hongos, pp. 52-66 in Tópicos selectos en Fitopatología: Genética Molecular, edited by J. P. MARTínez-SoRIANo, Sociedad Mexicana de Fitopatología, Irapuato, México.

HARTL, D. L. and A. G. Clark (1997): Principles of population genetics. $3^{\text {rd }}$ edition, Sinauer, Sunderland, USA.

Ho, K. Y., C. H. OU, J. C. YANG and J. Y. Hsiao (2002): An assessment of DNA polymorphisms and genetic relationships of Casuarina equisetifolia using RAPD markers. Bot. Bull. Acad. Sin. 43: 93-98.

Jones, N. and J. BuRLEY (1973): Seed certification, provenance nomenclature and genetic history in forestry. Silvae Genet. 22: 53-58.

KAMAU, E., S. MAYES and A. BARRETT (2003): Isolation and characterization of microsatellite loci in Scizolobium parahyba (Leguminosae). Mol. Ecol. Notes 3: 469-470.

KARP, A. and K. J. EDWARDS (1995): Molecular techniques in the analysis of the extent and distribution of genetic diversity, pp. 11-22 in Molecular Genetic Techniques for Plant Genetic Resources, edited by INTERNATIONAL Plant Genetic Resources Institute (IPGRI), Rome, Italy.

MontenEGro, F. (1987): Plantaciones Forestales Productivas en los Trópicos de Ecuador con Pachaco, Schizolobium parahyba, Análisis Económico de las Invesiones en Plantaciones Forestales en Ecuador. INIAP, Quito, Ecuador.

Mougel, C., J. Thioulouse, G. Perriere and X. Nesme (2002): A mathematical method for determining genome divergence and species delineation using AFLP. Int. J. Syst. Evol. Microbiol. 52: 573-586.

Muluvi, G., J. Sprent and N. Soranzo (1999): Amplified Fragment Length Polymorphism (AFLP) analysis of genetic variation in Moringa oleifera Lam. Mol. Ecol. 8: 463-470.

NEI, M. (1978): Estimation of average heterozygosity and genetic distance from a small number of individuals. Genetics 89: 583-590.

NEI, M. and W. H. LI (1979): Mathematical model for studying genetic variation in terms of restriction endonucleases. Proc. Natl. Acad. Sci. USA 76: 5269-5273.
Pejic, I., P. Ajmone-Marsan, M. Morgante, V. KazumPlick, P. Castigliani, G. Taramina and M. Motto (1998): Comparative analysis of genetic similarity among maize inbred lines detected by RFLPs, RAPDs, SSRs, and AFLPs. Theor. Appl. Genet. 97: 1248-1255.

Powell, W., M. Morgante and C. Andre (1996): The comparison of RFLP, RAPD, AFLP and SSR (microsatellite) markers for germplasm analysis. Mol. Breed. 2: 225-238.

Ribeiro, M. M., G. Le Provost, S. Gerber, G. G. VenDRAmin, M. Anzidei, S. DecroocQ, A. Marpeau, S. MariETTE and C. PlOMion (2002): Origin identification of maritime strands in France using chloroplast simplesequence repeats. Ann. For. Sci. 59: 53-62.

SAlvadoR, L., R. AlíA, D. AGúnDEZ and L. GIL (2000): Genetic variation and migration pathways of maritime pine (Pinus pinaster Ait) in the Iberian Peninsula. Theor. Appl. Genet. 100: 89-95.

Skroch, P., J. TIVANG and J. NiEnhuIs (1992) Analysis of genetic relationships using RAPD markers data, pp. 26-29 in Applications of RAPD technology to plant breeding, edited by CROP SCIENCE SocIETy OF AMERICA, Madison/WI.

SHARMA, S., M. KNox and T. ElLIS (1996): AFLP analysis of the diversity and phylogeny of lens and its comparison with RAPD analysis. Theor. Appl. Genet. 93: $751-758$.

SzMidT, A., X. WANG and M. LU (1996): Empirical assessment of allozyme and RAPD variation in Pinus sylvestris (L.) using haploid tissue analysis. Heredity 76: $412-420$.

Tipan, G. (1982): El Pachaco. Centro Forestal Conocoto del INIAP, Quito, Ecuador.

Thomas, B., S. McDonald, M. Hicks, D. AdAms and R. HodGETTS (1999): Effects of reforestation methods on genetic diversity of lodgepole pine: an assessment using microsatellite and randomly amplified polymorphic DNA markers. Theor. Appl. Genet. 98: 793-801.

Vos, P., R. Hogers, M. Bleeker, M. ReiJans, T. van DE Lee, M. H, A. Frijters, J. Pot, J. Peleman, M. Kuiper and M. ZABEAU (1995): AFLP: A new technique for DNA fingerprinting, Nucl. Acids Res. 23: 4407-4414.

White, G. and W. Powell (1997): Isolation and characterisation of microsatellite loci in Swietenia humilis (Meliaceae): an endangered tropical hardwood species, Mol. Ecol. 6: 851-860.

Williams, J., A. KubeliK, K. LivaK, J. RAFALSKI and S. TINGEY (1990): DNA polymorphisms amplified by arbitrary primers are useful as genetic markers, Nucl. Acids Res. 18: 6521-6535. 